\title{
Study of the high prevalence and cardiovascular risk factors: students aged 11 to 16 years from Caceres-Spain and Paranavaí-Brazil
}

\author{
Walcir Ferreira-Lima', Silvia B. Silva-Lima', Flávia E. Bandeira-Lima², Fellipe Bandeira-Lima³, Amanda Santos ${ }^{3}$, \\ Alynne C. Andaki ${ }^{4}$, Jorge Mota ${ }^{3}$, Carlos A. Molena-Fernandes ${ }^{2}$, Juan P. Fuentes ${ }^{1}$
}

'Universidad de Extremadura. Facultad de Ciencias del Deporte. ${ }^{2}$ Universidade Estadual do Norte do Paraná - Brasil. Departamento de Educação Física. ${ }^{3}$ Universidade do Porto. Porto. Portugal. Faculdade de Desporto Porto. ${ }^{4}$ Universidade Federal do Triângulo Mineiro. Minas Gerais. Brasil. Departamento de Educação Física.

doi: 10.18176/archmeddeporte.00011

Received: 01/05/2020

Accepted: $11 / 09 / 2020$

Key words:

Exercise. Cardiovascular diseases. Risk factors. Students.

\section{Summary}

Objective: to investigate the association of risk factors for the development of cardiovascular diseases in students from 11 to 16 years old in different contexts.

Material and method: Sample composed by students of Cáceres - Spain $(n=165)$ and Paranavaí - Brazil $(n=237)$. Body Mass Index, level of physical activity, blood pressure, total cholesterol, low- and high-density lipoproteins, triglycerides and fasting blood glucose were analyzed. For the analysis of variables, the Kolmogorov-Smirnov tests, Student t, Mann-Whitney U, Chisquare, and Odds Ratio were used, with a 95\% confidence interval, a value of $p<0.05$ was considered statistically significant. Results: Spanish students have higher average values of age, physical activity level, obesity in general, low- and high-density lipoproteins and fasting blood glucose ( $\mathrm{p}<0.05)$. Brazilians had a greater accumulation of risk factors compared to the Spanish, specifically only $8.5 \%$ of Brazilians are exempt from RF compared to $28.2 \%$ of Spanish. It is observed that there is a higher prevalence of two RFs (G-BRA: 40.7\% vs. G-ESP: 24.2\%); and three or more RF (G-BRA 27.0\% vs. G-ESP: 13.7\%), considering a value of $p<0.001$. Being more active was associated with HDL levels among Brazilians. Although Spanish students had a higher prevalence of general obesity, they were more active.

Conclusion: Spanish students showed better results in physical activity levels, fasting glucose concentration, high and low density lipoproteins, in addition to a lower number cardiovascular risk factors, despite being mainly from public schools; with higher average age and higher general obesity prevalence, compared to Brazilians.

\section{Estudio de alta prevalencia de factores de riesgo cardiovasculares: estudiantes de 11 a 16 años de Cáceres-España y Paranavaí-Brasil}

\section{Resumen}

Objetivo: Investigar la asociación de factores de riesgo para el desarrollo de enfermedades cardiovasculares en estudiantes de 11 a 16 años en diferentes contextos.

Material y método: Muestra compuesta por estudiantes de Cáceres - España $(n=165)$ y Paranavaí - Brasil $(n=237)$. Se analizaron el Índice de Masa Corporal, el nivel de actividad física, la presión arterial, el colesterol total, las lipoproteínas de baja y alta densidad, los triglicéridos y la glucosa en sangre en ayunas. Para el análisis de variables, se utilizaron las pruebas de Kolmogorov-Smirnov, $t$ de Student, $U$ de Mann-Whitney, Chi-cuadrado y Odds Ratio, con un intervalo de confianza del 95\%. Un valor de $p<0,05$ fue considerado estadísticamente significativo.

Resultados: Los estudiantes españoles tienen valores promedio más altos de edad, nivel de actividad física, obesidad en general, lipoproteínas de baja y alta densidad y glucosa en sangre en ayunas $(p<0.05)$. Los brasileños tuvieron una mayor acumulación de Factores de Riesgo en comparación con los españoles, específicamente solo el 8,5\% de los brasileños están exentos de Factores de Riesgo en comparación con el 28,2\% de los españoles. Se observa que existe una mayor prevalencia de dos Factores de Riesgo (G-BRA: 40,7\% vs. G-ESP: 24,2\%); y tres o más Factores de Riesgo (G-BRA 27,0\% vs. G-ESP: 13,7\%), considerando un valor de $p<0,001$. Ser más activo se asoció con los niveles de lipoproteínas de alta densidad entre los brasileños. Aunque los estudiantes españoles tenían una mayor prevalencia de obesidad general, eran más activos.

Palabras clave:

Ejercicio. Enfermedades cardiovasculares. Factor de riesgo. Estudiantes.
Conclusión: Los estudiantes españoles mostraron mejores resultados en niveles de actividad física, concentración de glucosa en ayunas, lipoproteínas de alta y baja densidad, además de un menor número de factores de riesgo para enfermedades cardiovasculares, a pesar de que provienen en su mayoría de escuelas públicas; con mayor edad media y mayor prevalencia de obesidad general.

Correspondence: Walcir Ferreira Lima

E-mail: walcirflima@gmail.com; walcirflima@uenp.edu.br 


\section{Introduction}

Cardiovascular risk factors (RF) can be classified as unchangeable - such as inheritance, sex and age - and changeable - such as level of physical activity (LPA); Body Mass Index (BMI); blood pressure (BP); the plasma concentrations of total cholesterol (TC), of triglycerides (TG), high density lipoprotein ( $\mathrm{HDL}$ ) and fasting glucose (FG). A lack of physical activity is an important risk factor (RF) of morbidity and premature mortality, as well as the high costs of medical assistance associated with hypokinetic pathologies'. Cardiovascular diseases (CVD) can be linked to a lack of physical activity, particularly regarding diseases of multi factor-origin².

Society's lifestyle exposes its youngest members to RF at an extremely early age, leaving them vulnerable to develop morbidities that can continue well into adulthood. Infancy and adolescence are characterised as suitable periods for developing interventionist strategies in the fight against CRF, once there is scientific evidence that these illnesses may originate during this stage of life $e^{2}$. The careful planning and effective execution of interventions focused on promoting health, aiming to reduce the probability of suffering from CVD in adulthood, can be efficient with the early identification of the presence of these RF in children and young people ${ }^{3}$.

The lifestyle of children and adolescents in different countries, such as Spain and Brazil, is directly linked to the obesogenic setting, as both Brazilians and Spaniards are influenced - for diverse reasons - to adopt unhealthy behavioural habits ${ }^{4}$. The obesogenic environment is characterised by the influence that the surrounding conditions have on opportunities and the lifestyle choices of individuals, which facilitate the development of obesity, as well as adopting inappropriate food choices and sedentary behaviour.

The option of carrying out a study linked to the lifestyle of children and adolescents from two mainland cities, was determined by the fact participants belonged to countries with differences, such as: country size, the number of inhabitants in the country, as well as cultural, social and economic differences, whilst also displaying similarities such as the number of schools and inhabitants in the city, and the strong Spanish influence - as colonizer of the city of Paranavaí ${ }^{\text {- }}$ - bringing with it a similar yet geographically distant genetic inheritance, and above all, a lack of other research studies of these characteristics.

Comparisons related to the incident/prevalence rate of HR predisposing to CVD carried out on students from countries with the characteristics of this research study are relatively scarce, i.e., according to information from the United Nations ${ }^{6}$, they can be found in different conditions of human development, with a Human Development Index (HDI) of values ranging from 0 to 1, considering health, income and education indicators. The closer to 0 , the worse the human development of the city; in this perspective, the city of Cáceres (Spain) presented an $\mathrm{HDI}$ of 0.876 (very high), and the city of Paranavaí (Brazil), an HDI of 0.755 (high).
High-risk behaviour for cardiovascular health influenced by sociodemographic characteristics should be considered when promoting the health of children and adolescents ${ }^{7}$. An appropriate analysis of the prevalence of RF of changeable illnesses, both among Spanish and Brazilian students, far from large cities, is relevant in determining the prevalence and understanding the behaviour of these factors in these demographics, allowing for the innovation and re-development of interventions towards a healthy lifestyle.

In this respect, the aim of this study was to research the link between LPA and RF in the development of CVD in students aged 11 to 16 years in different contexts

\section{Material and method}

This is a cross-cutting observational research study ${ }^{8}$; the sample groups comprised students from state and private schools in Spain and Brazil. In Spain, the data was collected between May and September 2015 from students in their 1st-3rd year of compulsory secondary education, whilst data was collected in Brazil in Paranavaí between July and August 2013 , from students in their 6th year of primary education - 1st year of compulsory secondary education.

The sample size comprised 80 individuals, estimated a priori using G*Power software, version 3.1.9. ${ }^{9}$ with an alpha level defined at 0.05 and a statistical power of $95 \%$.

The students that fulfilled the following criteria were included in the sample selection: aged between 11 and 16 years on the date of data collection; having signed a consent form to participate in the research study with their parents or legal guardian(s); participation in all the tests linked to the study; a school attendance rate of at least $75 \%$ on the date of data collection. All the students in the classes selected were invited to participate in the research study, however, those that did not fulfil the aforementioned inclusion criteria were excluded, as well as those that had any kind of impediment to performing sports - particularly health related - except for problems that constituted the focus of this research study Figure 1

The predisposing RF to CVD analysed were LPA, determined as a behavioural-type factor, and in the biological field, information was used to discover the BMI, the resting BP, and circulating blood levels of $\mathrm{CT}, \mathrm{HDL}, \mathrm{TG}$ and FG.

The information about the LPA was assessed using the International Physical Activity Questionnaire - (IPAQ-A) modified for adolescents ${ }^{10}$ referring to the previous week (barely active $<300$ min./week) ${ }^{11}$.

Standing height was measured, using an aluminium stadiometer attached to scales with a reading precision of $0.01 \mathrm{~m}$; body mass was recorded in kg using a Filizola brand mechanical weighing scale, with $100 \mathrm{~g}$ precision, and a maximum capacity of 150 kg; the body mass index (ratio between body mass in $\mathrm{Kg}$ and the height squared in $\mathrm{m}$.), in accordance with the cut-off points adjusted by age and sex proposed by Cole, et al ${ }^{12}$

The blood pressure measurement was taken using a correctly calibrated and validated instrument. Study participants remained seated for at 
Figure 1. Representation diagram of the sample of students, SPA-G (2015) and BRA-G (2013).

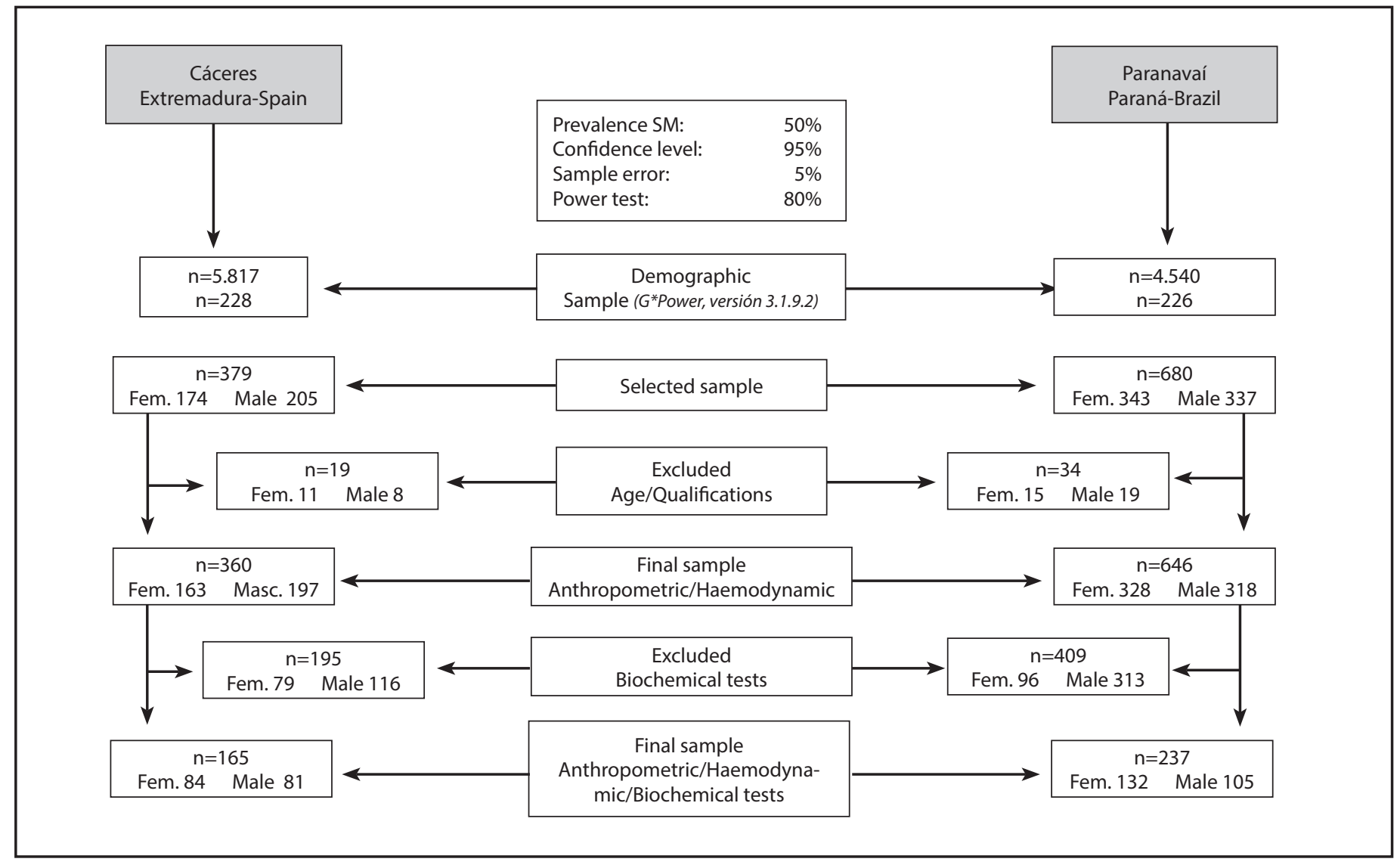

least five minutes, with their feet on the ground and their arms resting at chest height. An appropriate-sized cuff was used (which circled at least 80.0\% of the arm). Two measurements were taken: systolic blood pressure (SBP) and diastolic blood pressure (DBP), recorded using the auscultation method with the help of a mercury column blood pressure cuff, adaptable to the students' arm circumference size, taken whilst seated for at least five minutes. Two measurements were taken, the average score of which was used for the analysis corresponding to this study variable (high $\mathrm{BP} \geq$ 90 percentile) $)^{13}$.

Serum levels of TC, HDL, TG and FG were measured using the colorimetric enzymatic method, with Gold Analisa kits. The Brazilian students underwent laboratory tests in the LEPAC and the Inflammation Laboratory of the Universidade Estadual de Maringá (UEM), whilst the Spanish students were tested in private laboratories in Cáceres. For the biochemical analyses, $10 \mathrm{ml}$ samples of venous blood in the ulnar artery vein were taken, following a fasting period of at least 10 hours. Levels were considered of RF TC $\geq 200 \mathrm{mg} / \mathrm{dL} ; \mathrm{HDL}<40 \mathrm{mg} / \mathrm{dL} ; \mathrm{TG} \geq 150 \mathrm{mg} / \mathrm{dL}$ and $F G \geq 100 \mathrm{mg} / \mathrm{dL}^{14}$.

The data collected was handled using the computerised package Statistical Package for the Social Science (SPSS), version 26.0. To analyse the numerical variables, descriptive statistic procedures were used (absolute and relative frequency), then, depending on the results of the
Kolmogorov-Smirnov normality test, to identify the differences between sexes, the Student $t$ test (averages comparison) was performed, along with the Mann-Whitney $U$ test (distribution functions) for the variables with parametric and non-parametric distributions, respectively. Categorical variables (proportion based on the considered cut-off points) were analysed using crossed tables, with Chi-squared $\left(X^{2}\right)$ and Cramer y Phi' ${ }^{15}$ $V$ tests, to identify statistical differences between the groups (Bonferroni method) ${ }^{16}$. The Odds Ratio (OR) estimations, with a confidence interval of $95 \%$, were performed to analyse the links between the different RF. A value of $p<0.05$ was considered statistically significant for all the analyses.

The intervention protocols were authorised in Brazil by the Ethics Committee for research involving humans of the Universidade Estadual de Maringá, section 353,552, and in Spain by the Bioethical and Biosafety Commission of the University of Extremadura, registry number 52/2015. All parents or tutors of the students under 18 years, signed a free and informed consent form.

\section{Results}

165 students participated in the study in Cáceres ExtremaduraSpain (SPA-G), 51.6\% were boys, more than half aged between 15-16 
years (53.2\%), from state compulsory secondary education centres (80.6\%). In Paranavaí, Paraná, Brazil (BRA-G) 237 students participated, of which $56.1 \%$ were girls, aged between $11-12$ years (48.7\%), from a private primary education centre (55.0\%).

When comparing the groups, it was observed that the distribution of the variables for the markers associated with the RF in CVD was not the same, except between the average DBP values. The Spanish students had higher average values for: age, LPA, general obesity, plasma levels of $\mathrm{HDL}$, LDL, and fasting glucose, as well as lower average values for: TC and TG compared to the Brazilian students. $(p<0.05)$, results displayed in Table 1.

The comparisons between the proportions of students that presented cardiovascular risk indicators are displayed in Table 2. Both groups revealed a high prevalence of the majority of RF associated with CVD, with some values favourable to the students from the SPA-G - such as the proportion of "not very active" (40.3\% compared to $51.9 \%$, $p=0.046)$ - and subjects with high TC $(3.2 \%$ vs. $46.0 \%, p<0.001)$ for
Spanish and Brazilian students, respectively. No statistical differences were found between the proportions of the remaining RF.

The results of the simultaneous presence of one or more RF for CVD in each of the students and their respective proportions, are displayed in Figure 2. The BRA-G students displayed results with greater RF accumulations compared to the SPA-G, specifically, only $8.5 \%$ of the Brazilian students are free from RF compared to $28.2 \%$ of the Spanish students. Likewise, there is a higher prevalence of the two RF (BRA-G: $40.7 \%$ vs. SPA-G: $24.2 \%$ ); and three of more RF (BRA-G $27.0 \%$ vs. SPA-G: $13.7 \%$ ), considering a value of $p<0.001$. With the complementary analysis of the number of RF by sex, statistically significant differences were observed, which continued in the two sub-groups; both the girls and boys from Spain had a lower prevalence in accumulating RF compared to the students from the BRA-G.

The association between LPA and biological indicators predisposing to CVD is displayed in Table 3. Just one link was observed between HDL and LPA in the BRA-G, with more active students approximately 3 times

Table 1. Description of the averages, means and tests referring to risk factors for cardiovascular disease, SPA-G (2015) and BRA-G (2013).

\begin{tabular}{|c|c|c|c|c|c|c|c|}
\hline & \multicolumn{3}{|c|}{ G-SPA $(n=165)$} & \multicolumn{3}{|c|}{ G-BRA $(n=237)$} & \multirow[b]{2}{*}{$p$-value } \\
\hline & Average $\pm d p$ & Median & $(\min -\max )$ & Average $\pm d p$ & Median & $(\min -\max )$ & \\
\hline Age (years) & $14.4 \pm 1.2$ & 14.6 & $(11.3-16.4)$ & $12.7 \pm 334.6$ & 12.5 & $(10.6-16.4)$ & $0.001^{* *}$ \\
\hline LPA (min/week) & $466.9 \pm 386.1$ & 360.0 & $(0-2310)$ & $387.4 \pm 334.7$ & 270 & $(30-1470)$ & $0.025^{* *}$ \\
\hline $\mathrm{BMI}(\mathrm{Kg} / \mathrm{m} 2)$ & $21.0 \pm 3.3$ & 20.5 & $(15.0-3.3)$ & $20.1 \pm 3.6$ & 19.7 & $(12.3-31.8)$ & $0.009^{* *}$ \\
\hline $\mathrm{SBP}(\mathrm{mmHg})$ & $115.1 \pm 13.4$ & 114.3 & $(77-145)$ & $111.1 \pm 15.9$ & 111.0 & $(68-152)$ & $0.018^{*}$ \\
\hline $\mathrm{SBD}(\mathrm{mmHg})$ & $64.5 \pm 8.4$ & 64.7 & $(49.5-94)$ & $65.5 \pm 12.3$ & 64.0 & $(40-103)$ & $0.730^{* *}$ \\
\hline $\mathrm{TC}(\mathrm{mg} / \mathrm{dL})$ & $155.6 \pm 22.7$ & 154.0 & $(106-220)$ & $200.0 \pm 44.4$ & 195.8 & $(98.2-317.4)$ & $0.001^{*}$ \\
\hline $\mathrm{HDL}(\mathrm{mg} / \mathrm{dL})$ & $55.9 \pm 12.0$ & 56.0 & $(29-92)$ & $49.0 \pm 6.8$ & 49.6 & $(29.9-61.8)$ & $0.001^{* *}$ \\
\hline LDL (mg/dL) & $84.5 \pm 19.9$ & 85.0 & $(36-156)$ & $59.6 \pm 39.1$ & 62.0 & $(6.4-192)$ & $0.048^{* *}$ \\
\hline TG (mg/dL) & $76.4 \pm 32.8$ & 66.5 & $(27-218)$ & $85.6 \pm 42.2$ & 74.5 & (32.3-277.6) & $0.048^{* *}$ \\
\hline $\mathrm{FG}(\mathrm{mg} / \mathrm{dL})$ & $91.4 \pm 6.0$ & 91.0 & $(78-115)$ & $78.8 \pm 16.7$ & 77.5 & $(45.1-121.2)$ & $0.001^{* *}$ \\
\hline
\end{tabular}

LPA: level of physical activity; BMI: Body Mass Index; SBP: systolic blood pressure; DBP: diastolic blood pressure; TC: total cholesterol; HDL: high density lipoprotein; TG: triglycerides; FG: fasting glucose; SPA-G: Spanish Group; BRA-G Brazilian Group; SD: standard deviation. *t-Student Test; **Mann-Whitney Test.

Table 2. Proportion (\%) of students that presented risk factors predisposing to cardiovascular diseases, SPA-G (2015) and BRA-G (2013).

\begin{tabular}{|c|c|c|c|c|c|c|}
\hline & \multicolumn{2}{|c|}{ SPA-G $(n=165)$} & \multicolumn{2}{|c|}{ BRA-G $(n=237)$} & \multirow[b]{2}{*}{$\mathbf{X}^{2}$} & \multirow[b]{2}{*}{$p$-value } \\
\hline & f & (\%) & f & $\%$ & & \\
\hline LPA (<300 min/week) & 66 & 40.3 & 123 & 51.9 & 3.993 & 0.046 \\
\hline $\mathrm{BMI}\left(\geq 25 \mathrm{Kg} / \mathrm{m}^{2}\right)$ & 37 & 22.6 & 59 & 24.9 & 0.215 & 0.643 \\
\hline $\mathrm{BP}$ ( $\geq 90$ percentile) & 47 & 28.2 & 74 & 31.2 & 0.319 & 0.572 \\
\hline $\mathrm{TC}(\geq 200 \mathrm{mg} / \mathrm{dL})$ & 5 & 3.2 & 109 & 46.0 & 66.534 & $<0.001$ \\
\hline $\mathrm{HDL}(<40 \mathrm{mg} / \mathrm{dL})$ & 9 & 7.3 & 23 & 9.5 & 0.488 & 0.485 \\
\hline LDL ( $\geq 130 \mathrm{mg} / \mathrm{dL})$ & 3 & 1.6 & 10 & 4.2 & 1.662 & 0.197 \\
\hline $\mathrm{TG}(\geq 150 \mathrm{mg} / \mathrm{dL})$ & 25 & 15.3 & 54 & 22.8 & 2.601 & 0.107 \\
\hline $\mathrm{FG}(\geq 100 \mathrm{mg} / \mathrm{dL})$ & 12 & 7.3 & 30 & 12.7 & 2.350 & 0.125 \\
\hline
\end{tabular}

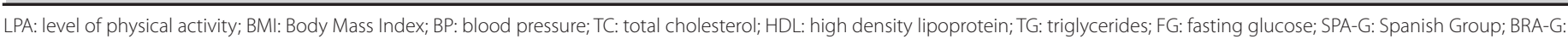
Brazilian Group; X2: Chi-squared Test. 
Figure 2. Proportion (\%) of students that simultaneously presented Risk Factors predisposing to cardiovascular diseases, SPA-G (2015) and BRA-G (2013).

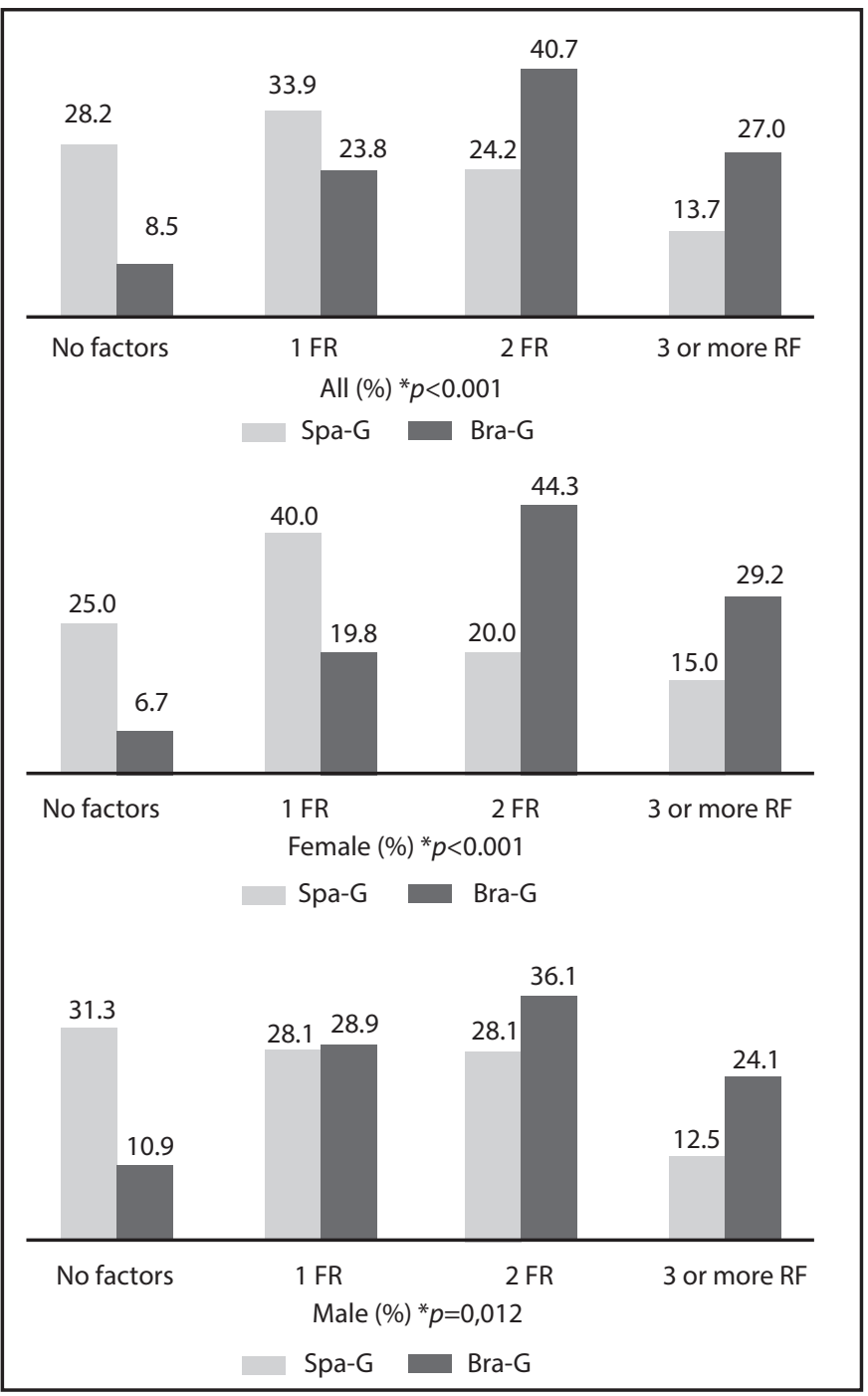

*Statistically significant difference between groups. more likely to have higher HDL serum levels than their peers (CI 95\%): 1.059-9.078; $p=0.039$ ), with no other significant link between the other $\mathrm{RF}$ in any of the groups.

\section{Discussion}

When analysing the group averages, it was confirmed that regarding the RF for CVD, there were no differences between the DBP values, differing from trends found in other studies ${ }^{17}$. In turn, differences were found for the other averages, supporting findings from other epidemiological research studies also carried out on a demographic of students of a similar age $\mathrm{e}^{18}$. These differences can be explained due to the typical hormonal changes that take place in this age group in both sexes ${ }^{19}$. For example, the temporary high concentration of TC and its fractions is due to a higher production of oestrogen occurring in females at this stage; whilst the greater production of testosterone in boys is linked to higher blood pressure levels ${ }^{20}$. Cultural, environmental and social models inherent to each region or country can also influence, and perhaps explain, the differences between the studies ${ }^{21}$.

The TG values found were lower than those from other research studies ${ }^{22}$; also differing from an epidemiological study that did not find any differences between the averages ${ }^{23}$. The Spanish students revealed higher BMI and LPA averages than their Brazilian counterparts (21.0 \pm 3.3 vs. $20.1 \pm 3.6, p=0.009$ ) and (466.9 \pm 386.1 vs. $387.4 \pm 334.7$, $p=0.025)$ respectively, results that could be linked to the older average age of the SPA-G students.

On the other hand, when analysing the proportions found in the groups, high prevalence of physical inactivity observed in the two groups (SPA-G $=40,3 \%, B R A-G=51.9 \%, p=0.046)$, coinciding with a research study which in turn, revealed that girls were less active than boys ${ }^{24}$. The proportion of overweight and obese students (SPA-G $=22.6 \%, B R A-G=24.9 \%$, $p=0.643$ ) is an aggravating factor, considering that excess body weight during childhood and adolescence usually becomes entrenched with

Table 3. Association between LPA and predisposing indicators to cardiovascular diseases, in students, SPA-G (2015) and BRA-G (2013).

\begin{tabular}{|c|c|c|c|c|c|c|}
\hline & \multicolumn{3}{|c|}{ SPA-G $(n=165)$} & \multicolumn{3}{|c|}{ BRA-G $(n=237)$} \\
\hline & Value & (low-upp) & p-value & Value & (low-upp) & $p$-value \\
\hline BMI $\left(\geq 25 \mathrm{Kg} / \mathrm{m}^{2}\right)$ & 0.635 & $(0.261-1.548)$ & 0.318 & 0.764 & $(0.395-1.480)$ & 0.425 \\
\hline BP $(\geq$ perc. 90$)$ & 1.157 & (0.524 90-2.558) & 0.718 & 1.149 & $(0.620-2.130)$ & 0.658 \\
\hline $\mathrm{TC}(\geq 200 \mathrm{mg} / \mathrm{dL})$ & 0.483 & $(0.049-4.780)$ & 0.534 & 0.991 & (0.559-1.756) & 0.974 \\
\hline $\mathrm{HDL}(<40 \mathrm{mg} / \mathrm{dL})$ & 0.833 & $(0.212-3.269)$ & 0.794 & 3.100 & (1.059-9.078) & 0.039 \\
\hline $\mathrm{LDL}(\geq 130 \mathrm{mg} / \mathrm{dL})$ & 1.490 & $(0.091-24.385)$ & 0.780 & 1.577 & $(0.366-6.796)$ & 0.541 \\
\hline TG ( $\geq 150 \mathrm{mg} / \mathrm{dL})$ & 1.405 & $(0.526-3.751)$ & 0.498 & 0.855 & $(0.433-1.689)$ & 0.653 \\
\hline $\mathrm{FG}(\geq 100 \mathrm{mg} / \mathrm{dL})$ & 1.200 & $(0.306-4.707)$ & 0.794 & 0.625 & $(0.263-1.488)$ & 0.288 \\
\hline
\end{tabular}

BMI: Body Mass Index; BP: blood pressure; TC: total cholesterol; HDL: high density lipoprotein; LDL: low density lipoprotein; TG: triglycerides; FG: fasting glucose; SPA-G: Spanish Group; BRA-G: Brazilian Group; confidence interval; Low: lower; Upp: upper. 
adulthood: just $20 \%$ of individuals tend to reduce and maintain body weight within expected levels when adults ${ }^{25}$.

Students that perform very little physical activity can be influenced to simultaneously adopt other types of behaviour that are harmful to their health, such as smoking and/or alcohol consumption, sedentary lifestyles and the consumption of unhealthy foods; in this respect, the early prevention and monitoring of weight can be effective alternatives to fight most of these issues ${ }^{26}$.

The elevated BP proportions (SPA-G = 28.2\%; BRA-G = 31.2\%; $p=0.572$ ) are higher values than those found in similar studies carried out in Latin America ${ }^{27}$ and Spain ${ }^{28}$. Related longitudinal studies regarding BP have demonstrated that young people with high BP levels tend to maintain these high levels and are diagnosed with high blood pressure in adulthood ${ }^{29}$. These high BP levels suggest that it could be a common characteristic in this age group (11-16 years).

The indicators associated with abdominal obesity - an important cardiovascular risk factor - were studied in the same sample and have been published in another article ${ }^{30}$. Another situation that requires special attention is the large proportion of students that displayed at least one RF predisposing to CVD (SPA-G $=71.8 \%$, BRA-G $=91.5 \%$ ), with the subgroup of BRA-G girls deserving particular attention due to the number of students exempt from RF (25.0\% vs. 6.6\%; $X^{2}=23.280$; $p<0.001$; SPA-G vs. BRA-G, respectively). The possibility of CRF appearing and developing early is greater when there is a higher number of accumulated RF (three or more: SPA-G $=13.7 \%, B R A-G=27.0 \%$ ), even more concerning with scientific evidence that these RF identified during adolescence tend to remain in the future ${ }^{31}$. Likewise, the simultaneous presence of two or more RF is a highly noteworthy result in both groups, given the extremely young age of the subjects.

In the BRA-G, the least active students displayed a lower concentration of HDL than those with sufficient activity levels. This result supports the epidemiological study suggesting better results related to HDL concentration among those considered more active ${ }^{32}$. HDL levels tend to lower during adolescence in both sexes, but they are more accentuated among boys ${ }^{33}$.

The groups presented similar characteristics in terms of a high prevalence of RF, not revealing links between the RF. On the other hand, it should be noted that the results from the Spanish students revealed that, even with a higher prevalence of excess weight, they were more active than their Brazilian peers.

In this study, particular attention could be given to the fact that similarities and differences were objectively presented between students from different countries, in terms of cultural, social and economic aspects, from an inland Spanish city compared to a city colonised by the Spanish located in inland Brazil. The research study provides results that confirm the increase of cardiovascular RF prevalence in samples of students aged 11 to 16 years, results that could be useful for developing and developed countries alike.

The methodology used and the use of instruments translated and adapted to assess the LPA and the analysis of the other RF, were the same in both groups. The students participating in the study were constrained to a narrow age band, a factor that could help minimise the potential effects of the pubertal differences in the parameters measured.

The cross-cutting conception of the research does not provide evidence about the causes, merely the presence or not of associations between the study variables; however, the results indicated the existence of occasional yet crucial differences, particularly regarding the RF

Targeted efforts are necessary to benefit fully from this life phase, in which girls and boys are receptive to incorporating healthy lifestyle practices through to adult age, by developing actions in each of these countries in the context of school ${ }^{34}$, socio-familiar, in the media, and by competent authorities designing regular and on-going educational programmes.

The prevalence of CVD RF found in Spanish and Brazilian students is concerning, both given the complexity of these factors as well as due to the students being young children, meaning they may be exposed to these factors for a much longer time, favouring undesirable outcomes in terms of health.

The SPA-G students were slightly older and were mostly from state schools, and, in theory, should have revealed worse results than their Brazilian counterparts. Countries with worse human development indices present less healthy data in cardiovascular risk factors, with the exception of the USA ${ }^{35}$. This result is considered to be linked to the type of environment in which the students live and are exposed to, as well as sedentary lifestyles and unhealthy eating habits

\section{Conclusion}

The Spanish students revealed better results in physical activity levels, fasting glucose concentration, high and low density lipoproteins, as well as a lower number of risk factors for cardiovascular diseases, despite most of the students attending state schools, with an older average age and higher prevalence of general obesity compared to the Brazilian students. It is key to encourage students to improve their lifestyles to reduce the evolution of these $\mathrm{RF}$, and to develop strategies that lead to reduced risks, for example, in the form of regular physical exercise and a healthy diet.

\section{Funding source}

Coordenação de Aperfeiçoamento de Pessoal em Nível Superior (CAPES) - Brazil - bolsas de estudos de Doutorado Pleno - Ciência sem Fronteiras. Processes BEX 13 482-13-0 e BEX 13374-13-3.

\section{Conflict of interest}

The authors claim to have no conflict of interest whatsoever.

\section{Bibliography}

1. Ding D, Lawson KD, Kolbe-Alexander TL, Finkelstein EA, Katzmarzyk PT, van Mechelen $W$, et al. The economic burden of physical inactivity: a global analysis of major noncommunicable diseases. The Lancet. 2016;388:1311-24. 
2. Sherar LB, Cumming SP, Eisenmann JC, Baxter-Jones AD, Malina RM. Adolescent biological maturity and physical activity: biology meets behavior. Pediatr Exerc Sci. 2010;22:332-49.

3. Simão A, Precoma D, Andrade J, Correa Filho H, Saraiva J, Oliveira G, et al. I Diretriz Brasileira de Prevenção Cardiovascular. Arq. Bras. Cardiol. 2013;101:1-63.

4. Fisberg M, Maximino P, Kain J, Kovalskys I. Ambiente obesogênico-oportunidades de intervenção. J Pediatr. 2016;92:S30-S9.

5. De Montoya AR, Rabuske A. Conquista espiritual feita pelos religiosos da Companhia de Jesus nas Províncias do Paraguai, Paraná, Uruguai e Tape. Martins Livreiro Editor; 1985.

6. Reports HD. Indicadores Internacionales de Desarrollo Humano http://hdr.undp.org/ es: United Nations Development Programme; 2014.

7. Leal MABF, Lima CEBd, Mascarenhas MDM, Rodrigues MTP, Paiva SSCd, Sousa CRdO, et al. Associação entre fatores sociodemográficos e comportamentos de risco à saúde cardiovascular de adolescentes brasileiros com 13 a 17 anos: dados da Pesquisa Nacional de Saúde do Escolar 2015. Epidemiol. Serv. Saúde. 2019;28, e2018315.

8. Aguiar P. Guia prático climepside estatística em investigação epidemiológica:SPSS. Lisboa: Climepsi Editores, 2007.

9. Faul F, Erdfelder E, Lang A-G, Buchner A. G* Power 3: A flexible statistical power analysis program for the social, behavioral, and biomedical sciences. Behav. Res. Methods. 2007;39:175-91.

10. Hagströmer M, Bergman P, De Bourdeaudhuij I, Ortega FB, Ruiz JR, Manios Y, et al. Concurrent validity of a modified version of the International Physical Activity Questionnaire (IPAQ-A) in European adolescents: The HELENA Study. Int J Obes. 2008;32:S42-S8.

11. Strong WB, Malina RM, Blimkie CJR, Daniels SR, Dishman RK, Gutin B. et al. Evidence based physical activity for school-age youth. J Pediatr. 2005;146:732-7.

12. Cole TJ, Bellizzi MC, Flegal KM, Dietz WH. Establishing a standard definition for child overweight and obesity worldwide: international survey. BMJ. 2000;320:1240.

13. Christofaro DGD, Casonatto J, Polito MD, Cardoso JR, Fernandes R, Guariglia DA, et al. Evaluation of the Omron MX3 Plus monitor for blood pressure measurement in adolescents. Eur J Pediatr. 2009;168:1349-54.

14. Zimmet P, George K, Alberti MM, Kaufman F, Tajima N, Silink M, et al. The metabolic syndrome in children and adolescents - an IDF consensus report. Pediatr Diabetes. 2007;8:299-306.

15. Pan C-C, Davis R, Nichols D, Hwang SH, Hsieh K. Prevalence of overweight and obesity among students with intellectual disabilities in Taiwan: A secondary analysis. Res Dev Disabil. 2016;53:305-13.

16. Fu Y, Gao Z, Hannon JC, Burns RD, Brusseau Jr TA. Effect of the SPARK Program on Physical Activity, Cardiorespiratory Endurance, and Motivation in Middle-School Students. JPAH. 2016;13:534-42.

17. Cauduro A, Bergmann M, Bergmann G. Atividade física, sobrepeso e pressão arterial: associação independente e combinada em adolescentes. RBAFS. 2015;20:483.

18. Lima MCC, Romaldini JH. Frequency of obesity and related risk factors among school children and adolescents in a low-income community. A cross-sectional study. Sao Paulo Med J. 2015;133:125-30.

19. Tanner JM. Growth and maturation during adolescence. Nutr Rev. 1981;39:43-55.

20. Moran A, Jacobs DR, Steinberger J, Steffen LM, Pankow JS, Hong C-P, et al. Changes in insulin resistance and cardiovascular risk during adolescence establishment of differential risk in males and females. Circulation. 2008;117:2361-68.
21. Ferreira RW, Rombaldi AJ, Ricardo LIC, Hallal PC, Azevedo MR. Artigo original: Prevalência de comportamento sedentário de escolares e fatores associados. Prevalence of sedentary behavior and its correlates among primary and secondary school students (English). Rev. Paul. Pediatr. 2016;34:56-63.

22. Friedemann C, Heneghan C, Mahtani K, Thompson M, Perera R, Ward AM. Cardiovascular disease risk in healthy children and its association with body mass index: systematic review and meta-analysis. BMJ. 2012, 345: e47592012.

23. Rizzo AC, Goldberg TB, Silva CC, Kurokawa CS, Nunes HR, Corrente JE. Metabolic syndrome risk factors in overweight, obese, and extremely obese Brazilian adolescents. Nutr J. 2013;12:19

24. Martínez-Baena A, Mayorga-Vega D, Viciana J. Relación de los niveles de actividad física con el género y el perfil de riesgo cardiovascular en adolescentes granadinos. Implicaciones didácticas para la educación física. Profesorado, Revista de Currículum y Formación del Profesorado. 2016;20:265-85

25. Bastien M, Poirier P, LemieuxI, Després J-P. Overview of epidemiology and contribution of obesity to cardiovascular disease. Prog Cardiovasc Dis. 2014; 56:369-81.

26. Franks PW, Hanson RL, Knowler WC, Sievers ML, Bennett PH, Looker HC. Childhood obesity, other cardiovascular risk factors, and premature death. NEJM. 2010;362:485-93.

27. Christofaro D, Ritti-Dias R, Chiolero A, Fernandes R, Casonatto J, Oliveira A. Physical activity is inversely associated with high blood pressure independently of overweight in Brazilian adolescents. SJMSS. 2013;23:317-22.

28. Marrodán SM, Cabañas AM, Carmenate MM, González-Montero dEM, Lopez-Ejeda N, Martínez Ás, et al. Association between adiposity and blood pressure levels between the ages of 6 and 16 years. Analysis in a student population from Madrid, Spain. Rev Esp Cardiol. 2013;66:110-15.

29. Kelly RK, Magnussen CG, Sabin MA, Cheung M, Juonala M. Development of hypertension in overweight adolescents: a review. Adolesc Health, Med Ther. 2015;6:171-87.

30. Lima WF, da Silva-Lima SB, Lima FÉB, Lima FB, Fernandes CAM, Mota JAPS, et al. Indicadores associados à obesidade abdominal em estudantes brasileiros e espanhóis de 11 a 16 anos de idade. RBONE. 2018:12:756-66.

31. Andersen LB, Wedderkopp N, Hansen H, Cooper A, Froberg K. Biological cardiovascular risk factors cluster in Danish children and adolescents: the European Youth Heart Study. Prev Med. 2003;37:363-7.

32. Silva MJC, Martini FAN, Neto AS, Corrêa RC. Associação da atividade física e prática esportiva com os fatores de risco metabólicos e força da musculatura respiratória em crianças obesas. Saúde em Revista. 2016;16(43):21-8.

33. Bloch KV, Szklo M, Kuschnir MCC, de Azevedo Abreu G, Barufaldi LA, Klein CH, et al. The Study of Cardiovascular Risk in Adolescents-ERICA: rationale, design and sample characteristics of a national survey examining cardiovascular risk factor profile in Brazilian adolescents. BMC Public Health. 2015:15:1-10.

34. Silva M, Engers P, Vilela G, Spohr C, Rombaldi A. Fontes de informação sobre benefícios à prática de atividade física e fatores associados em adolescentes: estudo de base escolar. RBAFS. 2016;21:237-45

35. Sbaraini M, Cureau FV, Sparrenberger K, Teló GH, Kuschnir MCC, Oliveira JS, et al. Severity of obesity is associated with worse cardiometabolic risk profile in adolescents: Findings from a Brazilian national study (ERICA). Nutrition. 2020:110758. 